\title{
MANQUL: COMMUNICATING THE MESSAGE OF GOD TO THE DIVERSE ISLAMIC DISCIPLINES
}

\author{
MANQUL: PENYAMPAIAN PESAN TUHAN \\ KEPADA PENGIKUT ISLAM YANG BERAGAM
}

\author{
Darman Fauzan Dhahir \\ Balai Besar Pengembangan SDM dan Penelitian Komunikasi dan Informatika \\ Jl. Abdurrahman Basalamah II No.25, Makassar \\ Email: darmanfauzan@gmail.com
}

Naskah diterima tanggal 9 agustus 2018, Naskah direvisi tanggal 8 Oktober 2018, Naskah disetujui tanggal 5 November 2018

\begin{abstract}
Muslims are obliged to perform duties for worship properly and correctly. They are widely spread all over the world with a low Islamic literacy. Being a Muslim is just a bandwagon for them, thus they do worship without clear reference. The scholars do not give up on the situation by conducting the Qur'an and Hadith based Islamic teachings through various mediums. The famous mediums have several weaknesses that ultimately indicate how hard messages are delivered. The delivery is increasingly heavy due to the low literacy Arabic language, and reading interest. In the midst of this situation, LDII as one of the Muslim communities has a growing number of members and is widespread in Indonesia, a country which also has many low-literacy Arabic citizens. The alumni are even widely spread abroad. Therefore, this study aims to find out how the teaching methods applied by the community. The finding was the community has been practicing anancient method, namely Manqul. It is a continued message delivery technique from the God as the communicator to the whole human being as the communicant through the messengers who really understand the messages they carry as well as practice them. They apply a unique technical writing to strengthen memories, and use the addition of auxiliary words to facilitate understanding to diverse disciples, even to those with low Arabic literacy and low reading interest. They deliver and preserve the Qur'an and the Hadith by both text and meaning.
\end{abstract}

Keywords: Textual translation, education communication, Manqul.

\begin{abstract}
Abstrak
Umat Islam wajib melakukan ibadah dengan baik dan benar. Umat tersebar luas di seluruh dunia dengan kemampuan keaksaraan yang rendah. Menjadi seorang Muslim hanyalah ikut-ikutan bagi sebagian mereka. Mereka melakukan ibadah tanpa referensi yang jelas. Para ulama tidak menyerah pada situasi ini dengan melakukan ajaran Islam berdasarkan Al-Qur’an dan Hadits melalui berbagai media. Media terkenal memiliki beberapa kelemahan yang pada akhirnya menunjukkan pesan sulit disampaikan. Pengirimannya pesan semakin berat sebab rendahnya kemapuan Bahasa Arab, dan minat baca. Di tengah situasi tersebut, LDII sebagai salah satu komunitas Muslim memiliki anggota yang bertambah banyak dan tersebar luas di Indonesia, sebuah Negara yang memiliki banyak penduduknya memiliki literasi Bahasa Arab yang rendah. Alumni komunitas tersebut bahkan tersebar luas ke manca negara. Oleh karena itu penelitian ini ingin mencari tahu bagai mana metode pengajaran yang diterapkan oleh komunitas tersebut. Penelitian ini menemukan bahwa LDII telah mempraktekkan metode kuno, yaitu Manqul. Teknik ini adalah teknik pengiriman pesan yang berkelanjutan, dari Allah sebagai komunikator kepada seluruh manusia sebagai komunikan melalui para pembawa pesan yang benar-benar memahami pesan-pesan yang mereka bawa serta mempraktikkannya. Mereka menerapkan teknik menulis untuk memperkuat ingatan, dan menggunakan penambahan kata bantu untuk memfasilitasi pemahaman kepada murid yang beragam, bahkan bagi mereka yang memiliki kemampuan berbahasa Arab rendah dan minat baca rendah. Mereka menyampaikan dan melestarikan Al-Qur'an dan Hadis dengan teks dan makna.
\end{abstract}

Kata kunci: Terjemahan, tekstual, komunikasi, pendidikan, Manqul. 


\section{INTRODUCTION}

\section{The Message of God}

$\mathrm{E}$ very Muslim is obliged to obey Allah and the Messenger in order to be admitted into the heaven(Qur'an, n.d., Chapter 4: 13, 4: 59). To perform the obligations properly and correctly, Muslim should first understand what rules to obey, the Qur'an and the Hadiths indeed. The Qur'an isa book containing 114 chapters or 6,236 verses of commands, prohibitions, and stories of God those had beensent down to the Prophet MuhammadSAW(Salla-Allahu Alaihi Wa-sallamal peace and blessings of Allah be upon him)(Haleem, 2011, p. 6; Santosa, Nurkamto, Baidan, \& others, 2016)the objectives of this study are to assess the sub directive speech acts contained in the verses of the stories and the dominant directive speech acts. The research target is the verses (ayat; and the Hadiths are books which are containing everythingbased on the Prophet SAWin the form of words, actions, approvals,and natures those were narrated and transmitted continuouslyby trusted people and well-documented by the Hadith-book authors, (AlUtayminn, 1994; Harpci, 2015; Haylamaz, 2014). It is also believed as the (indirect) message of God, but in the ProphetSAW's version indeed (Qur'an, n.d., Chapter 53: 3-4).

Both are the main sources of knowledge in Islam, the right paths which should be followed (Abi-Dawūd, 2007, v. 2885; Ibn-Ānas, 1985, v. 899) for the entire life of all Muslim. Even whenthey find a confusion and/or disagree over anything and/or have a dispute concerning any matter, then they are ordered to seek references from the both (Qur'an, n.d., Chapter 4: 59).

\section{Delivering the Message of God}

The delivery of the Qur'an and the Hadithhas become an obligation of all Muslimas the God claimed that Islam is a universal religion and ordered the Prophet $S A W$ and the followers to convey the messages to all humankind over the world. For that, there should be no distinction between the scholar and the low-literacy, the rich and the poor, the Arabian and (Arab-)foreigner (Qur'an, n.d., Chapter 21: 107, 3: $104 \&$ 110, 80: 1). At the moment, Islam has been spread widely throughout the world, but with a lot of muallaf, the new convert followers (Kettani, 2010; Moon, Kobayashi, \& Suh, 2006) and/or those are still poor on sharia (Islam law) literacy. For this reason, they need the guidance of implementation of Islam(Ismawati, 2012; Johari, Ali, Aziz, \& Ahmad, 2014). Another reason is to open the eyes of the world so that the negative image addressed to Islam can be clarified whether it's true or not (Ali, Salem, Oueslati, Andrew, \& Quirke, 2011; Oueslati, McAndrew, \& Helly, 2011).

But then, most of the guidanceare preserved in Arabic, since the Qur'an was first revealed in that language to the Prophet SAW who natively spoke it. It is only Arabic version isconsidered as the only real directwords of God, the true Qur'an. In Islam, Arabic is the best language (Haleem, 2011). Even the Prophet SAWhas made Sunna (exemplified) on it. He applied Arabic when he wrote letters of invitation to Islam to Heraclius the emperor of Byzantines, Khosrow the emperor of Persia, and Najashi the king of Abyssinia. But however, the emperors had translators indeed (El-Cheikh, 1999; Grabar, 2003; Peysepar \& Attashi, 2016).

Nevertheless, in order to achieve the communication goals, the abroad followers as the communicantsmust be led to understand the message(Nasrullah, Kriantono, \& Sujoko, 2018). But, the deliveryof the messages to the foreign-speaking people would not be an easy job, since the diversity of the communicants has been animportant factor that able to thwart the communications (Rung-Yu Tseng, Chuang, Hermann, Koehler, \&Ellen YiLuen Do, 2011). Furthermore, when two people with different languages communicate, they will be sound less credible each other (Lev-Ari \& Keysar, 2010). Moreover, if the communicants are the lowliteracy or those who have low reading interest, it would be more difficult indeed. To overcome this problem, they must be led to master the language or be given to the translation in order that the messages are clearly understood. Unfortunately, the mastery of Arabic by the Arabic-foreigners is still very poor (Lobachev, 2008) and either, the Qur'an and the Hadith have not been translated properly (Elmgrab, 2013; Jassem, 2014; Nikayin, 2017; Xue-yi, 2010), hence the readings of those bothIslamic guidance have been considered by the majority of Muslim asonly spells or poetry, not as something that has a meaningof being a guide of life(Estivalèzes, 2011; Hasibuan, 2014, p. xii; Sodhar, Shaikh, \& Sodhar, 2015). It is even happening in Indonesia (Ismawati, 2012; Puyu, 2016; Sholeh, 2018), the home of the world's largest Muslim population(Heryanto \& Mandal, 2004).

However, practitioners outside Arabic countries do not give upon the situation. Islamic 
teachings in the Qur'an and Hadith are remain conducted. Medium they utilize, such as: Islamic schools (Hamdeh, 2015; Novia, 2015), mosques (Ghazali, Yusof, Md. Sawari, \& Shah, 2016; Mughal, 2015), door to door engagements (Balci, 2012; Siyami \& Musawwamah, 2015), books (Leichtman, 2009), television(Rofil, Md Syed, \& Hamzah, 2016; Siagian, Mustari, \& Ahmad, 2016), radio(Sakai \& Fauzia, 2014), and internet (Mahmood \& Qayyum, 2015). They apply several techniques, such as lectures (Dohrn, 2014), preachments (Millie, 2011), readings (Ramli, Majid, \& Nazri, 2013; Sudrajat, 2016, p. 17), articles and translation book providing (Zulkefli, Rahman, Bakar, \& Alam, 2015), and application-examples (Dohrn, 2014).

In Islamic (boarding) school, students will learn complete subject matters, such as: Arabic grammar, technique of the Qur'an reading well and truly (tajwïd), logic, jurisprudence and its principles (Fiqh and usül al-fiqh), doctrine of monotheism, the Qur'an exegesis, the Hadiths, the science of hadith, piety and appropriate behavior (akhlaq and tarbïya), Sufism(tasawwuf), life histories of the Prophet SAW(sïra) and works in praise of the Prophet. They are classified according to their knowledge level into primary, secondary and high levels ofthree years each, as well as the advanced level, a no limited time level. They need long enough time to be allowed to learn the main guidance, due they are supposed to spend at least their first six years on the basic knowledge mastery before learning the Qur'an and the Hadith (Bruinessen, 1990; Sumardi, 2012).On the same level, the studentsare usually average peers. Almost of all the techniques are applied in the process of teaching-learning there (Fatchan, Amirudin, \& Soekamto, 2015; Wekke, 2015). Unfortunately, there is only a low number of Muslim can achieve the advanced level (Bakri, 2017; BR, 2015).

Commonly, Muslims prefer to listen to preachment speeches in Mosques, or trough television and radio broadcasts, especially for those who have a low reading interest (Kumbara, 2008; Yusof, 2010). Unfortunately, this technique has several weaknesses, they are: (1) The preacher is difficult to understand the audience understanding of the materials presented; (2) It is only the preacher who is active, while the audience is passive; (3) It is difficult to explore the mindset of the audience and their attention; and (4) The preacher tend to be authoritarian(Faisal, 2014). The mass media, such as television, and radio hasvarious communication methods,besides has a wide range, heterogeneous audiences, but it is occasionally doubtful because sometimes there is a mixture of truth and fallacy/ heresy in it (Atabik, 2013).

Some others of Muslim choose to read books as reference, and some more prefer to access the internet, the convergence media to find lectures, preachment speeches, readings, examples in form of articles, book, audio and/or video. Both of them are the active audience learning styles. The success of this style will depend on their literacy, for several reasons: (1) The missing-translations are frequently happening due to limitedness of the translators (Newmark, 1996, p. 101); (2) Theanonymous authors of internet content (Rob Kling, Ya-Ching Lee, Al Teich, 1999); (3) The hoaxes are spread in the internet (Arif, 2016); and (4) Even if the translator machines are continuously developed, so far, the level of accuracy is still minimal (Groves \& Mundt, 2015).

\section{LDII and Manqul}

This study will describe how LDII (Lembaga Dakwah Islam Indonesia/ Institution of Islam Preachment of Indonesia) community deliver the Qur'an and the Hadith to the diverse Muslims in style of Manqul. The informationhas been provided by the methods of participant-observation (at the habitation and learning centre of LDII in Indonesia, such as Java (Bandung, Bogor, Depok, Tangerang, Jakarta, Yogyakarta, Surabaya, Kediri, and Pamekasan), Sulawesi (Makassar, Palu, Manado, Polewali Mandar, Palopo, Selayar, Bantaeng, Gowa, Pangkep, Gorontalo, Kotamobagu, Minahasa, Baubau, and Sangihe), Nusa Tenggara (West Sumba, Belu, and Kupang), Bali, and Papua (Biak, Jayapura, Wamena, and Sorong)), interview (with muballig/preachers, leaders, and/or members) and discussion during 2016/2017.

LDII (Lembaga Dakwah Islam Indonesia/ Institution of Islam Preachment of Indonesia), as a community of Muslim in Indonesia which iswell developed enough.I did not find any valid data that showed the total number of them, but according to Hidayat Nahwi Rasul, one of LDII's central chairmen when interviewed at June 2016, the organization branches exist in all of 34 provinces in Indonesia.In a whole world recitation program held in the month of Ramadan (June) 2017, at the Wali Barokah Islamic boarding school, Kediri, some participants who came from outside Indonesia introduced themselves. They werealumnus who 
live in Australia, UK, USA, East Asia, and Middle Africa. The chairman's, the alumnus' information and my participant observation's results found the members are various in terms of literacies (from the school-less to the professor), ages (start from 8 years old), genders, cultures, languages (Javanese, Indonesian, English, Chinese, Japan, Korean, and Arabic), races, countries, urban \& rural,and jobs (the jobless, governmental/private officers, armies, traders, businessmen, farmers, fishermen, etc).

I found them see the situation of the conveyance of the God's message as an emergency, because they believe that Muslim should not wait to apply the orders of God as soon as they accept Islam as the faith, otherwise they will be put into hell. This is very often conveyed in recitations in all places which I have participated in. They argue that the appointment of death cannot be caused delay, nor advanced it in anticipation, whereas who has never earned righteousness through his/her faith, there will be no good for him/her (see Qur'an n.d., chap. 7: 34, 10: 49, 6: 158). Besides, the Prophet $S A W$ has exemplified that. When Muaz, his companion was sent to Yemen to invite them into Islam, he advised him to teach and order them to do the five prayers, and to pay zakat/regular charity (see ibn-Majah 2009, v. 1783).

They stress that Islam should be original/ authentic/pure (like Murtono (2014)'s finding) in terms of:

a. The intention: should be ihlas (only to gain the God blessing, not the worldly matters). They argue that ihlas is what the God has ordered and has been exemplified by the Messengers of God too (see Qur'an n.d., chap. 92: 19-21, 98: 5, 10: 72, 11: 29, 26: 109,127,145,164,180, 34: 47).

b. The references are the Qur'an and the Hadith. In faith application, they reject the no-Qur'an and Hadith's referenced-opinion. They argue that there is no reference will lead to the truth, but both references (see Qur'an n.d., chap. 6: 153; Bin-Anas 1985, 899). The God is the creator of Islam, then His guidance is the only ultimate true clue, not the other. They make a parable, "you would easily take a needle across the ocean if the person who laid it tells you completely and correctly, and you understand the clue, but you will find it difficult if you just guess."

c. The Application: should base on the true references, and precisely done as what the God has ordered and the Prophet exemplified. They argue that the deeds of Muslim who do bid'a (make something differ with the references or without clear reference) would be useless, even causing a punishment of God (see Qur'an n.d., chap. 4: 47; Al-Buhari 2009, v. 7350; AlNaisabury 2012, v. 53(400)).

Muslims are spread and various in terms of literacies, ages, genders, cultures, languages, races, countries, etc. They believe that all of them need to understand the message of God. Whoever has understood the message earlier, then he/she should apply it to his/her life anddeliver it to others, like the Prophet $S A W$ has (see Qur'an n.d., chap. 2: 78, 21: 107; Al-Buhari 2009, v. 1739; Al-Tirmidi 2013, v. 2669).

Hence, even its members are divers, they are determined that the diversity is not a barrier for them for delivering and/or receiving the God's message. It is very often conveyed in recitations in all places which I have participated in, that eventhe low mastery of Arabic (grammar, vocabularies, etc.) should not be an accepted reason for not doing it. They argued that Islam is a universal faith which not only for Arabian.Besides, the Prophet $S A W$ and his companions who were even ummi (unlettered) were also doing it (see Qur'an n.d., chap. 7: 157-8).

For that, the community applies the technique of Manqul(like Hijjang et al. 2015 has found) in delivering the message of the God, where translation is included. Manqul is an Arabic word that means something delivered and/or transferred. It is a concept of gaining the knowledge/information until someone understand the message from a narrator who has gained his/her knowledge/information from his/her guru(s) who had gained it from his/ her guru(s), and so on and so forth until it is based on the Prophet $S A W$.

I see here, the technique is actually similar to the Talqqi Bersanad, acontinuously maintainednarration of the Qur'anand the Hadith, from the full stop beginning to the end(Ramli et al., 2013). A verse of the Qur'an is exegeted by using other verses, the Hadith and/or explanation from the previous followers (closer to the Prophet $S A W$ would be better) and so is the exegesis of the Hadith.

The chairman of the Majelis Taujih wal Irsyad (Council of Missionaries) of LDII, Kasmudi Assidqistated at June 2017 that the manqul is practiced in seven grade ways as the previous ulama' (scholars) have practiced, they are (form the best): al-Sama' (the disciple listens to the narration of the guru)(see Abi-Dawūd, 2007, v. 3659), al-'Ard (the disciplenarrates, and the 
guru examines)(Abi-Dawūd, 2007, v. 3204), alMunawalabiijazaturrawi(the guru hands over the book to the disciple to be conveyed, for the guru, believes that he/she is able to understand the book and is able to convey), al-Munawalahbi gairiijazaturrawi(the guru hands over the book to the disciple to be practiced, not to be conveyed to others, for the guru believes that he/she is able to practice the book but has not been able to convey) (see Hamel, 1999), al-Kitaba (disciple reads the letter that the guru sends), al-Ijazatu al-rawi (the guru give permission to the disciple to share the narration of him/her)(see Al-Buhari, 2009, v. 1450), and al-Wijada (when someone findsa note of his/ her guruthat he/she really understand, then he/ she applies and/or shares it and tells the one he/she shares to that the narration was gained from the guru)(see Abi-Dawūd, 2007, v. 1108).

The members and even the alumnus who live abroad in Indonesia run their life normally as common people while continuing to apply the manqul, whether as a muballig or a disciple. They claim that the Prophet was practicing the Manqul too. They refer to ibn-Majah (2009, v. 1621) and Al-Buhari (2009, v. 3219) which tell that the Gabriel recited/taught the Qur'an to the Prophet $S A W$. They also refer to the explanation of the Prophet on the exegesis of the Qur'an (chap. 2: 187) about time for fasting. It was a verse which reads that a Muslim is allowed to eat and drink until white thread become distinct to them from the black thread.

Then a companion of Him was eating while keep watching both the thread until he was able to see the difference. It was then corrected and explained by the Prophet $S A W$, based on the God's revelation, that the meaning was the rising of dawn (see Al-Naisabury 2012, vv. 1090-1). The practice of the manqul is appropriate to the community's mission to make the Qur'an and the Hadith to be easily and clearly understood by as much as possible of Muslim in order that those both books to be truly applied as the prime guidance of their life.

\section{Practice of Manqul}

As long as the observation I had been conductingduring 2016/2017 at the habitation and learning centre of LDII in Indonesia, such as Java (Bandung, Bogor, Depok, Tangerang, Jakarta, Yogyakarta, Surabaya, Kediri, and Pamekasan), Sulawesi (Makassar, Palu, Manado, Polewali Mandar, Palopo, Selayar, Bantaeng, Gowa, Pangkep, Gorontalo, Kotamobagu, Minahasa, Baubau, and Sangihe), Nusa Tenggara (West Sumba, Belu, and Kupang), Bali, and Papua (Biak, Jayapura, Wamena, and Sorong), it was only the al-Sama' applied I found.

The disciples were listening and writing to the reading of the muballig.Their example of writing is available in Figure 1. Even when sending a letter(al-Kitaba),there was always a messenger or representative sent to receive and bring the message back and read it to his/her member group.The messenger is required to be cleverbecause he/she is responsible for the understanding of his/her group members. Several interviewed muballigsin Jakarta, Kediri, Makassar, and West Sumba)explained that it was to ensure the message to be delivered well and correctly as aimed.

They claimed that the best reference is whatever refer to both text and context of both guidances, therefore they do not recommend teaching one of them alone. Their opinion is the same as Robarts (2008) who included a written version when delivering a message verbally. Besides, they believe that the ability of most Muslim nowadays to memorize the rules of religion (text and context) are low, because of the poor attention to religion matter. They think that even if someone has been told and understood a thing previously (but with no writing), he/she will be neglected by the worldly busyness, so then he/she will forget it. It is why the writing becomes the hallmark of this community, thus textbooks or sheets (of the Quran and the Hadith) and stationery are the minimum tools the disciples are required to have in every Manqulevent. Besides, the muballigh is prohibited to teach without the Qur'an orthe Hadith those completed with his/ her self-written notes of meaning and explanation (something he/she gained from his/her guru). Kasmudi Assidqi (interview in June, 2017) claimed it as an effort of keeping the purity of the both. 


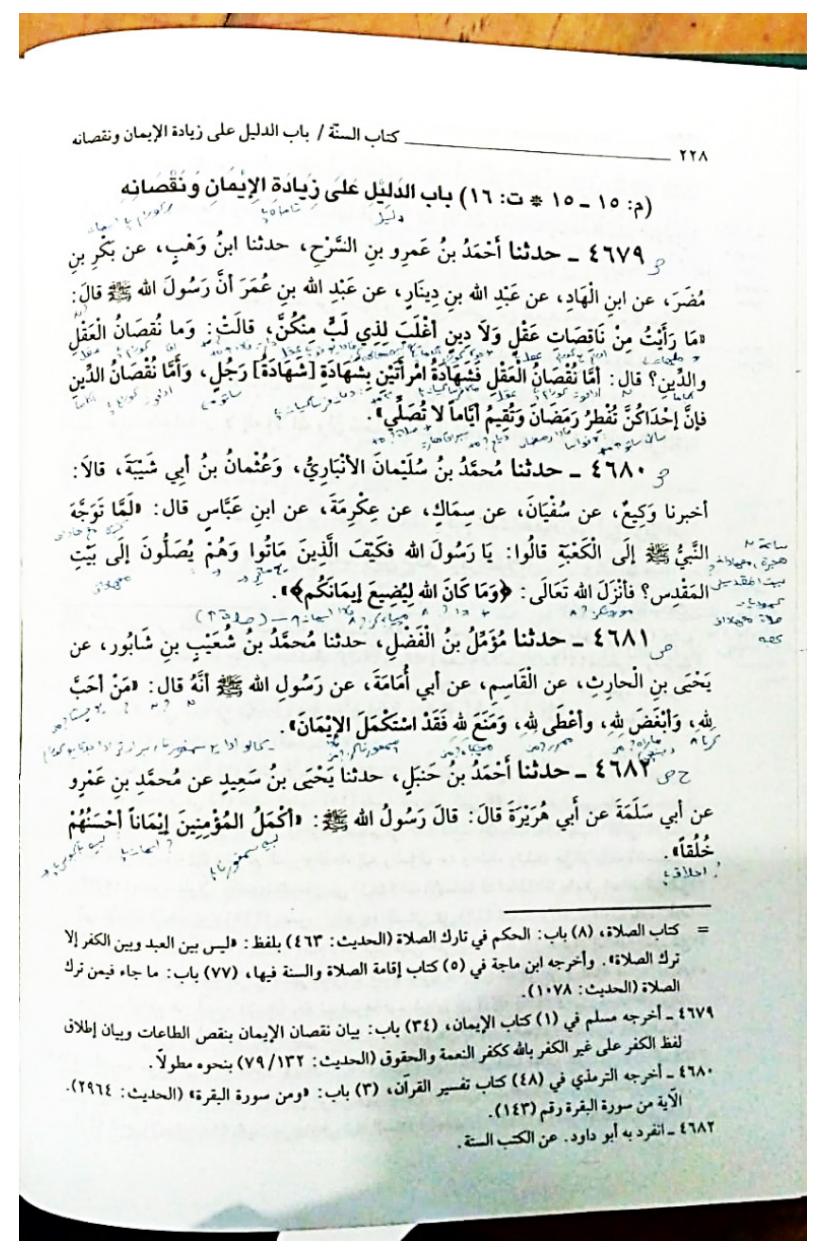

Figure 1. Hand-written translation on Hadith AbiDawūd

By the diversity of the members, then they translate theoriginal Arabic Qur'an orthe Hadith into three main languages, such as Javanese, Indonesian, and English. Kasmudi Assidqi (interviewed in June, 2017) explained why they use the original Arabic to translate. The reason is that many ways for the original meaningto deviate through the repeated translations, just similar to Ballesteros'(2000) argument.Practically, the muballigs translate and interpretthem by every single word, by the phrase, and by terminology, according to the chapters read or in sequence. Every word that is translated comes with explanationsbut is not exactly like a grammar lesson that uses code/ terms that is difficult to understand by laypeople. Commonly, they use simple auxiliaries such as, as for, who, whom, whose, what, that, apparently and that is, to describe words posing as subjects, objects, details, aliases, etc. Besides, the pronounsare usually immediately referred to the intended.
They do not focus on the linguistics, but on the meaning of the message and the how of its implementation instead, thus much of them (for example) able to recite the Qur'an match tothe tajwid science, but admitting that they do not understand about the tajwid. They also learn and practice the fiqh, tauhid, etc., but do not aware that it, in fact, is thefigh, tauhid, etc. Which they know, just if the Prophet $S A W$ exemplified that, and then they follow to do itaccording to the circumstances. The point is that, like a native speaker who does not need to be aware of the grammar as long as they understand what they are talking about or listening.

The disciples claim that by this method of the al-Sama' of manqul, the lessons are more easily accepted and applied. They become aware of the meaning of every single word of both references. By writing the lesson deliberately, it has helped their memory, unlike the reading ready-made translations, sometimes there are sentences that missing from the attention or are less understood. They make the expression of the parable: "it will be easy for someone to find a hidden treasure if he is directly told where it is, how to find it and how to take it by the one who keeps it, rather than someone who is told to self-learn the instructions". As a result of my participant-observation experience, I consider it as true. When I asked the community, why they practiced a worship in a certain way, most of them sure that it based on clear references because they have been read by the muballighs and read the verse from the books their selves, unlike the commonswho do worship just by the bandwagon(Siyami \& Musawwamah, 2015).

To follow the event as a disciple, the competencies someone are required to have are the ability of reading (silently) the Arabic letter (see Dykas and Sanders 2009), writing (in any style, essentially understood by the writer himself), and listening. A disciple who has not able to read the Arabic letter will be taught in advance. In their studying center (boarding school/school), when practicing the al-Sama',the disciples are classified according to their writing speed into three classes, such as lambatan (slow reading-dictation), cepatan (fast reading-dictation), and asrama (faster reading-dictation). In there, it takesonly about a single year forcompleting the reading, meaning and explanation writing of the whole Qur'an as well as about 20 subject matter summary sets of the Hadith. Whereas in the reading to the members at widespread places, the muballig normally adjust his/her reading speed to suit the audience. 
On the other hand, the practice of the alMunawala and the al-Ijazatu al-rawi is rare (but still exists) because of caution, lest it deviates from authenticity. The guru always examines the disciple's skills and understandings earnestly before applying it. The al-Wijada was less often, and even then if there is, then before it to be acknowledged, several studies should be conducted by experts. They check it's conformity with the postulates of the previously studied the Qur'an and the Hadith. If it is in accordance with the existing sciences, then accepted as the last preferred source of knowledge.

They keep continuing to hold manqulin order to preserve their faith, even though they have repeatedly reviewed the study or even they are the guru. They believe that faith can increase and decrease. In addition, without any discrimination, anyone of the disciples who havecompleted the Qur'an and certain Hadiths and has the ability to read the books well and correctly, may take the test to become a certified muballig. Unless they may share and discuss their manqulan (the knowledge they have gained by manqul) each other.

\section{CONCLUSION}

The manqul, a way to teach and learning the Qur'an and Hadith that continuely from guru to disciple has been practiced by the LDII Muslim community. This community continues to increase in number from time to time, and has alumni who are spread across the archipelago, as well as overseas. Members of this community consist of diverse ethnicities, languages, ages, education and occupations, including those who have low Arabic literacy.

Manqul's is following the ways of the earlier ulamasin the delivery of Islamic religion, as stated in the famous Hadith text. From several ways manqul, LDII practices Al-sama'more.Al-sama' is when the disciple listens to the narration of the guru, then they record it manually in their books. The guru translate the Qur'an and Hadith in words, use auxiliary words, then translate the whole and explain it. This method is believed to be easier to recall lessons that have been received, because at any time can reopen the books. Community members are very confident that the practices they practice are based on correct references, because they have seen the verse or hadith themselves. This method is a shortcut to be able to immediately practice the Quran and hadith without lingering on learning languages first.
The implication of this study, Manqul can be tested to be applied in learning using foreign language references, whether the lesson of religion or others. T he following research can compare the effectiveness of the manqul method to other methods.

\section{ACKNOWLEDGEMENT}

This research was partially supported by the Center for human resources development and communication and informatics research Makassar. I thank for the facilities provided and the colleagues who provided insight and expertise that greatly assisted the research, although they may not agree with all of the interpretations of this paper. I would also like to show my gratitude to LDII for sharing their information as well as pearls of wisdom with us during the course of this research, and we thank anonymous reviewers for their so-called insights.

\section{REFERENCES}

Abi-Dawūd, S. I. al-sijistānī. (2007). Sunan Abī Dawūd. Beirut: Dār El-Fikr.

Al-Buhari, I. (2009). Sahih al-Buhari (6th ed.). Beirut: Dar Al-Kotob Al-Ilmiyah.

Al-Naisabury, A.-I. A.-A.-H. M. B.-A.-H. A.-Q. (2012). Sahih Muslim (The autentic Hadith of Muslim) (4th ed.). Beirut: Dar Al-Kotob Al-Ilmiyah. Retrieved from http://al-ilmiyah.com

Al-Tirmidi. (2013). Al-Jami' al-sahih Sunan al-Tirmidy (4th (2 col). Beirut: Dar Al-Kotob Al-Ilmiyah.

Al-Uțaymīn, M. I. șalīh I. M. (1994). Muștalaḥul-hadìt. Cairo: Maktabah Al-'Ilm. Retrieved from http:// shamela.ws/index.php/book/21581

Ali, M. A., Salem, N., Oueslati, B., Andrew, M., \& Quirke, L. (2011). The Reduction of Islam and Muslims in Ontario's Social Studies Textbooks. Journal of Educational Media, Memory, and Society, 3(1), 2544. https://doi.org/10.3167/jemms.2011.030103

Arif, R. (2016). Internet as a Hope or a Hoax for Emerging Democracies: Revisiting the Concept of Citizenship in the Digital Age. Procedia - Social and Behavioral Sciences, 236, 4-8. https://doi. org/10.1016/j.sbspro.2016.12.002

Atabik, A. (2013). Prospek Dakwah Melalui Media Televisi. Jurnal Dakwah, 1(02), 191-209. Retrieved from http://journal.stainkudus.ac.id/index.php/ komunikasi/article/view/429

Bakri, M. A. (2017). Long Life Education Dalam Perspektif Islam. PILAR: Jurnal Ilmu-Ilmu Agama Kontemporer, 3(2), 212-227. Retrieved from http://journal.unismuh.ac.id/index.php/pilar/ article/view/472 
Balci, B. (2012). The rise of the Jamat al Tabligh in Kyrgyzstan: the revival of Islamic ties between the Indian subcontinent and Central Asia? Central Asian Survey, 31(1), 61-76. https://doi.org/10.108 $0 / 02634937.2012 .647843$

Ballesteros, L. A. (2000). Cross-Language Retrieval via Transitive Translation. In W. B. Croft (Ed.), Advances in Information Retrieval (pp. 203-234). Boston: Kluwer Academic Publishers. https://doi. org/10.1007/0-306-47019-5_8

BR, M. S. (2015). The Existence of Salafiyah Pondok Pesantren in The Middle of Urban Community. Al-Qalam, 17(2), 199-208. Retrieved from http:// www.jurnalalqalam.or.id/index.php/Alqalam/ article/view/113

Bruinessen, M. (1990). Kitab kuning; Books in Arabic script used in the Pesantren milieu; Comments on a new collection in the KITLV Library. Bijdragen Tot de Taal-, Land- En Volkenkunde / Journal of the Humanities and Social Sciences of Southeast Asia, 146(2), 226-269. https://doi. org/10.1163/22134379-90003218

Dohrn, K. (2014). Translocal Ethics: Hizmet Teachers and the Formation of Gülen-inspired Schools in Urban Tanzania. Sociology of Islam, 1(3-4), 233256. https://doi.org/10.1163/22131418-00104007

Dykas, F., \& Sanders, W. (2009). Mobius Annual Converence. Catalog 2009. Catalog Dept., University of Missouri. Retrieved from https:// www.loc.gov/catdir/cpso/romanization/

El-Cheikh, N. M. (1999). Muhammad and Heraclius: A Study in Legitimacy. Studia Islamica, (89), 5. https://doi.org/10.2307/1596083

Elmgrab, R. A. (2013). No Title. International Proceedings of Economics Development and Research, 44-49. https://doi.org/10.7763/IPEDR

Estivalèzes, M. (2011). Teaching about Islam in the History Curriculum and in Textbooks in France. Journal of Educational Media, Memory, and Society, 3(1), 45-60. https://doi.org/10.3167/ jemms.2011.030104

Faisal, F. M. (2014). Karakteristik Khitabah Jalaluddin Rakhmat (Studi Penelitian Deskriptif terhadap Karakteristik Khitabah KH Jalaluddin Rakhmat pada Pengajian Ahad di Masjid Al-Munawwarah, Kiara Condong, Bandung). UIN Sunan Gunung Djati Bandung. Retrieved from http://digilib. uinsgd.ac.id/id/eprint/2449

Fatchan, A., Amirudin, A., \& Soekamto, H. (2015). Education Model "Bandongan" for Farmers Society of Agricultural Skills Training in the Background of Sosioculture "Pesantren" in East Java*. Mediterranean Journal of Social Sciences, 6(5), 515. https://doi.org/10.5901/mjss.2015. v6n 5 p 515

Ghazali, M. A., Yusof, M. F., Md. Sawari, S. S., \& Shah, F. A.
(2016). Mosque as a Platform to Address the Issues of the Anti-Hadith in Malaysia. Mediterranean Journal of Social Sciences, 7(2 S1), 553. https://doi. org/10.5901/mjss.2016.v7n2s1p553

Grabar, O. (2003). The Story of Portraits of the Prophet Muhammad. Studia Islamica, (96), 19. https://doi. org/10.2307/1596240

Groves, M., \& Mundt, K. (2015). Friend or foe? Google Translate in language for academic purposes. English for Specific Purposes, 37, 112-121. https:// doi.org/10.1016/j.esp.2014.09.001

Haleem, M. A. (2011). Understanding the Qur'an: themes and style. London: IB Tauris. Retrieved from http://www.ibtauris.com/Books/Humanities/ Religion beliefs/Islam/The Koran/ /media/Files/ Extracts/Religion/9781845117894.ashx

Hamdeh, E. (2015). The Walking Qur'an: Islamic Education, Embodied Knowledge, and History in West Africa. The American Journal of Islamic Social Sciences, 32(1), 120-123. Retrieved from http:// search.proquest.com/docview/1688306091/?pqorigsite $=$ primo

Hamel, C. El. (1999). The Transmission of Islamic Knowledge in Moorish Society from the Rise of the Almoravids to the 19th Century. Journal of Religion in Africa, 29(1), 62. https://doi. org/10.2307/1581787

Harpci, F. (2015). 'Â'isha, Mother of the Faithful: The Prototype of Muslim Women Ulama. Al-Jamiah: Journal of Islamic Studies, 53(1), 159. https://doi. org/10.14421/ajis.2015.531.159-179

Hasibuan, M. (2014). 40 Kesalahan Persepsi dalam Memahami Al Quran. Elex Media Komputindo.

Haylamaz, R. (2014). Aisha: The Wife, The Companion, The Scholar. New Jersey: Tughra Books. Retrieved from http://www.tughrabooks.co/books/detail/ aisha-the-wife-the-companion-the-scholar

Heryanto, A., \& Mandal, S. K. (2004). Challenging Authoritarian Rule - SEA NIP. Routledge. https:// doi.org/10.4324/9780203060391

Hijjang, P., Sewang, A. M., Suhaeb, F. W., \& others. (2015). Recitation and Manqul the Basis of Social Capital Construction (A Study at Community of LDII in Makassar). International Journal of Academic Research, 7. Retrieved from http:// web.a.ebscohost.com/t?direct=true\&profile $=$ ehos $\mathrm{t} \&$ scope $=$ site \&authtype $=$ crawler $\&$ jrnl $=20754124$ $\& \mathrm{AN}=123624547 \& \mathrm{~h}=\mathrm{ETwL} \% 2 \mathrm{FnapmFqiJ53N3K}$ M9G74Jvua2sjMKfSSRDxJQ1R8eq4bzmfjn8LN1 Nzmc9MTy1MGa6NENXEbIWfo2ODckaw\%3D $\% 3 \mathrm{D} \& \mathrm{crl}=\mathrm{c} \&$ resultNs=AdminWebAuth\&resultL ocal $=\mathrm{E}$

Ibn-Ānas, A.-I. M. (1985). al-Muwatța’. Beirut: Dār Iḥyā’ al-Turāt al-'Arābī.

Ibn-Mājah, A.-I. (2009). Sunan Ibn Māja (The Sixth correct Tradition of Prophetic Sunna). (A. Samseddin, Ed.) 
(3th ed.). Beirut: Dar Al-Kotob Al-Ilmiyah.

Ismawati. (2012). Ikhtilāf al-Ṭabī'ah al-'Ilmīyah alIslāmīyah bayna Manātịq al-Sāḥil al-Shimālī wa al-Manāṭiq al-Dākhilīyah li Jāwah al-Wusțá fi al-Qarn 15-17 al-Mīlādī. Studia Islamika, 19(2), 313-347. https://doi.org/10.15408/sdi.v19i2.364

Jassem, Z. A. (2014). The Noble Quran: A Critical Evaluation of Al-Hilali and Khan's Translation. International Journal of English and Education 3 (2), 3(2), 237-273. Retrieved from http://www.ijee. org/yahoo_site_admin/assets/docs/21.83202107. pdf

Johari, F., Ali, A. F. M., Aziz, M. R. A., \& Ahmad, N. (2014). The Importance of Zakat Distribution and Urban-Rural Poverty Incidence among Muallaf (New Convert). Asian Social Science, 10(21), 4253. https://doi.org/10.5539/ass.v10n21p42

Kettani, H. (2010). 2010 World Muslim Population. In Proceedings of the 8th Hawaii International Conference on Arts and Humanities (pp. 1-61). Retrieved from https:/www.researchgate.net/ publication/268290952_2010_World_Muslim_ Population

Kumbara, A. A. N. A. (2008). Konstruksi Identitas Orang Sasak di Lombok Timur, Nusa Tenggara Barat. Jurnal Humaniora, 20(3), 315-326. Retrieved from https://jurnal.ugm.ac.id/jurnal-humaniora/ article/view/947

Leichtman, M. A. (2009). The Authentication Of A Discursive Islam. In M. Diouf \& M. A. Leichtman (Eds.), New Perspectives on Islam in Senegal (pp. 111-138). New York: Palgrave Macmillan US. https://doi.org/10.1057/9780230618503_6

Lev-Ari, S., \& Keysar, B. (2010). Why don't we believe non-native speakers? The influence of accent on credibility. Journal of Experimental Social Psychology, 46(6), 1093-1096. https://doi. org/10.1016/j.jesp.2010.05.025

Lobachev, S. (2008). Top languages in global information production. Partnership: The Canadian Journal of Library and Information Practice and Research, 3(2). https://doi.org/10.21083/partnership. v3i2.826

Mahmood, Z., \& Qayyum, A. (2015). Role of Social Media in the Light of Islamic Teaching. Al-Qalam, 20(2), 27-36. Retrieved from http://pu.edu.pk/images/ journal/alqalam/PDF/3.Dr. Abdul Qayyum CH+ Zaid Mahmood_Dec2015.pdf

Millie, J. (2011). Islamic preaching and women's spectatorship in West Java. The Australian Journal of Anthropology, 22(2), 151-169. https://doi. org/10.1111/j.1757-6547.2011.00132.x

Moon, H. R., Kobayashi, N., \& Suh, M. P. (2006). Porous Metal-Organic Framework with Coordinatively Unsaturated Mn II Sites:Sorption Properties for Various Gases. Inorganic Chemistry, 45(21), 8672-
8676. https://doi.org/10.1021/ic0611948

Mughal, M. A. Z. (2015). An anthropological perspective on the mosque in Pakistan. Asian Anthropology, 14(2), 166-181. https://doi.org/10.1080/168347 8X.2015.1055543

Murtono. (2014). Konsep Manquul dalam Perspektif Lembaga Dakwaj Islam Indonesia (LDII). Universitas Muhammadiyah Surakarta. Retrieved from http://eprints.ums.ac.id/32031/

Nasrullah, N., Kriantono, R., \& Sujoko, A. (2018). Interpersonal Communication Model of Prophet Muhammad SAW. WACANA, Jurnal Sosial Dan Humaniora, 20(3). Retrieved from http://wacana. ub.ac.id/index.php/wacana/article/view/501

Newmark, P. (1996). About translation. (D. Sharp, Ed.). Clevedon Philadelphia Adelaide: Multilingual Matters.

Nikayin, F. (2017). Quran: A poetic translation from the original. BookBaby.

Novia, S. U. (2015). The implementation of Islamic education in integrated Islamic Junior High School Al-Ghozali Jember. Universitas Islam Negeri Maulana Malik Ibrahim. Retrieved from http:// etheses.uin-malang.ac.id/5144/

Oueslati, B., McAndrew, M., \& Helly, D. (2011). Islam and Muslim Cultures in Quebec French-language Textbooks over Three Periods: 1980s, 1990s, and the Present Day. Journal of Educational Media, Memory, and Society, 3(1), 5-24. https://doi. org/10.3167/jemms.2011.030102

Peysepar, E., \& Attashi, A. (2016). The study of the sentence structure in the letters written by the Great Islam's Apostle (Peace be upon him). International Journal of Humanities and Cultural Studies (IJHCS), (2016), 2064-2071. Retrieved from http://www.ijhcs.com/index.php/ijhcs/index

Puyu, D. S. (2016). Paradigma fiqh al-hadis terhadap perilaku politik kontemporer. Jurnal Al-Qalam, 22, 117-130. Retrieved from http://jurnalalqalam. or.id/index.php/Alqalam/article/view/268/238

Quran. (n.d.). Quranic Arabic Corpus. Retrieved March 8, 2018, from http://corpus.quran.com

Ramli, F. Z. M., Majid, L. A., \& Nazri, M. A. (2013). Penerokaan Talaqqi Bersanad (TB) dalam Pengajian Hadis di Malaysia/ Exploration of Talaqqi with Sanad in Hadith Studies in Malaysia. Islamiyyat, 35(2), 67-76. Retrieved from http://search.proquest.com/docview/14918 00894? accountid=11929\%5Cnhttp://tt2mx4dc7s. search.serialssolutions.com/?ctx_ver $=$ Z39.882004\&ctx_enc=info: ofi/enc:UTF-8\&rfr_ id=info:sid/ProQ\%3Apqrl\&rft_val_fmt=info:ofi/ fmt:kev:mtx:journal\&rft.genre=article\&rft.jtitl

Rob Kling, Ya-Ching Lee, Al Teich. (1999). Assessing Anonymous Communication on the Internet: PolicyDeliberations. The InformationSociety, 15(2), 
79-90. https://doi.org/10.1080/019722499128547

Robarts, J. M. (2008). Practical Considerations for Distributed Agile Projects. In Agile 2008 Conference (pp. 327-332). IEEE. https://doi. org/10.1109/Agile.2008.57

Rofil, L. E. F., Md Syed, M. A., \& Hamzah, A. (2016). Bridging identities through religious television contents: Javanese female descendants, Islamic viewing and Malay identity projection. Asian Journal of Communication, 26(1), 42-57. https:// doi.org/10.1080/01292986.2015.1050041

Rung-Yu Tseng, Chuang, K., Hermann, K., Koehler, J., \& Ellen Yi-Luen Do. (2011). Hard to access the information in the healthcare system? I See! - an innovative touch-screen information board for pediatric hospitals. In 2011 IEEE International Conference on Pervasive Computing and Communications Workshops (PERCOM Workshops) (pp. 376-379). IEEE. https://doi. org/10.1109/PERCOMW.2011.5766910

Sakai, M., \& Fauzia, A. (2014). Islamic orientations in contemporary Indonesia: Islamism on the rise? Asian Ethnicity, 15(1), 41-61. https://doi.org/10.1 080/14631369.2013.784513

Santosa, R. B., Nurkamto, J., Baidan, N., \& others. (2016). Pragmatic Study of Directive Speech Acts in Stories in Alquran. Advances in Language and Literary Studies, 7(5), 78-84. Retrieved from http://www.journals.aiac.org.au/index.php/alls/ article/view/2605

Sholeh, M. M. A. (2018). Pola Penyimpangan Muslim Terhadap Ajaran Agamanya (Perspektif Pendidikan Islam). Al-Fikri: Jurnal Studi Dan Penelitian Pendidikan Islam, 1(1), 1-21. Retrieved from http://jurnal.unissula.ac.id/index.php/fikri/ article/view/2429/1841

Siagian, H. F., Mustari, \& Ahmad, F. (2016). the Position of Da'Wah Messages and Ethics in Malaysian and Indonesian Television Programs. Jurnal Komunikasi (Malaysian Journal of Communication), 32(2), 749-769. Retrieved from http://ejournals.ukm.my/mjc/article/view/16503
Siyami, F. B. L., \& Musawwamah, S. (2015). Problem Praktik Khuruj Bagi Anggota Jama’ah Tabligh di Madura. Al-Ihkam: Jurnal Hukum \& Pranata Sosial, 10(1), 145-168. Retrieved from http:// ejournal.stainpamekasan.ac.id/index.php/ alihkam/article/view/593

Sodhar, Z.-A., Shaikh, A. G., \& Sodhar, K.-N. (2015). Critical Analysis of The Challenges and Issues of Islam in The Modern World. Asia Pacific-Annual Research Journal of Far East \& South East Asia, 33, 96-106. Retrieved from http://sujo.usindh.edu. pk/index.php/ASIA-PACIFIC/article/view/918

Sudrajat, J. (2016). Memahami Belajar Entrepreneurship di Perguruan Tinggi. Yogyakarta: Deepublish.

Sumardi, K. (2012). Potret Pendidikan Karakter di Pondok Pesantren Salafiah. Jurnal Pendidikan Karakter, (3). Retrieved from https://journal.uny. ac.id/index.php/jpka/article/view/1246

Wekke, I. S. (2015). Arabic Teaching and Learning: A Model from Indonesian Muslim Minority. Procedia - Social and Behavioral Sciences, 191, 286290. https://doi.org/10.1016/j.sbspro.2015.04.236

Xue-yi, Q. I. (2010). The Hadith's Translation and Studies in China [J]. Journal of Beifang Ethnic University (Philosophy and Social Science), 1, 20. Retrieved from http://en.cnki.com.cn/Article_en/ CJFDTOTAL-XBDR201001020.htm

Yusof, M. A. (2010). Pengajaran dan pembelajaran pendidikan islam di masjid. In Seminar kebangsaan pengajaran dan pembelajaran berasaskan masjid 2010 (pp. 1-20). Fakulti Sains Sosial Gunaan Open University Malaysia. Retrieved from http:// library.oum.edu.my/repository/550/

Zulkefli, N. S. S., Rahman, N. A., Bakar, Z. A., \& Alam, S. (2015). Representation of Search Retrieval Results on Digital Hadith Online Browser. In Universiti Kebangsaan Malaysia International Colloquium of Graduates Islamic Studies 2015. Universiti Kebangsaan Malaysia. Retrieved from http:// prisma.uitm.edu.my/prisma/?doit=DirectoryStaf ByIdnTitleDetail\&pubId=VmtaYVUxSnJNVFpX VkZaT1lYcEdSbFl4VWxKTlZUbFNVRlF3UFE9 PQ\&pubType $=4$ 